\title{
INDONESIA DAN PERSAINGAN DI ERA ASEAN ECONOMIC COMMUNITY
}

\author{
Hendra Maujana Saragih ${ }^{1}$ \\ Dosen Tetap Program Studi Hubungan Internasional FISIP Universitas \\ Nasional \\ hendramaujanasaragih@civitas.unas.ac.id \\ hendramaujana@gmail.com
}

\begin{abstract}
This paper focusing on looking at Indonesia's readiness to deal with the Era of the Economic Community in ASEAN with the urgency that Indonesia's preparations should have a systemic impact on Indonesia's economic growth. The socialization that has been carried out continues and continues to be inflated by every child of the nation so as not to lose compete and be swallowed by the existence of regional countries that really use ASEAN Economic Community as a positive and constructive economic opportunity for each ASEAN member country officially. ASEAN Economic Community is one form of Free Trade Area (FTA) and located in Southeast Asia .ASEAN Economic Community which is formed with a mission to make the economy in ASEAN to be better and able to compete with countries whose economy is more advanced than the condition of ASEAN countries currently. The realization of ASEAN Economic Community, can make ASEAN a more strategic position in the international arena. Researchers expect that with the realization of the ASEAN economic community can open the eyes of all parties, resulting in an inter-sectoral dialogue that will also complement each other among the stakeholders of the economic sector in ASEAN countries and this is very inherent formally.
\end{abstract}

Keywords: Competition, Free Trade Area, Opportunity, Challenge

\footnotetext{
${ }^{1}$ Dosen Tetap Program Studi Hubungan Internasional Fakultas Ilmu Sosial dan Ilmu Politik Universitas Nasional Jakarta
} 


\section{PENDAHULUAN}

\section{A. Latar Belakang}

Kerjasama ASEAN telah menuju tahapan baru yang lebih integratif dan berwawasan ke depan ${ }^{2}$ dan diharapkan bisa memperkuat kerjasama ASEAN, adaptif dengan berbagai perubahan, tantangan, dan peluang. Hal ini membuka peluang bagi ASEAN untuk bisa bertransformasi sebagai organisasi yang solid dan kuat serta beorientasi pada kepentingan masyarakat (people-orieted).

Telah diketahui bahwa Cetak Biru Komunitas Ekonomi ASEAN merupakan rancang utama (master plan) untuk membentuk Komunitas ASEAN tahun 2015 yang lalu dengan mengidentifikasi langkah-langkah integrasi ekonomi yang ditempuh melalui implementasi berbagai komitmen yang rinci dengan sasaran dan jangka waktu yang jelas. ${ }^{3}$

Berkaitan dengan upaya untuk meningkatkan kesadaran akan Komunitas Ekonomi ASEAN (AEC Awareness), para Menteri Ekonomi ASEAN mengesahkan Rencana Komunikasi Komunitas Ekonomi ASEAN (AEC Communication Plan) dan menekankan pentingnya untuk melibatkan berbagai stakeholders dalam proses komunikasi, yaitu badan-badan sektoral ASEAN, sektor swasta, otoritas di tingkat lokal dan nasional di negara-negara ASEAN, kalangan akademi serta tokoh-tokoh masyarakat.

Berkenaan dengan itu, Pemerintah Indonesia melalui Kementrian Luar Negeri khususnya telah menyelenggarakan berbagai kegiatan seperti ASEAN Goes to School (AGTs), pemilihan Duta Muda ASEAN dari kalangan mahasiswa/i dari seluruh Indonesia, seminar ataupun kuliah umum untuk dosen, guru, mahasiswa dan pengusaha serta lomba simulasi sidang ASEAN di beberapa kota di Indonesia dengan maksud sosialisasi. ${ }^{4}$

\footnotetext{
${ }^{2}$ Dirjen Kerjasama ASEAN Djauhari Oratmangun, Kata Pengantar ASEAN Selayang Pandang Edisi ke 19 tahun 2010 hal. i ${ }^{3}$ Ibid, hal 3-4

${ }^{4}$ Ibid, hal 27
} 
Cukup mengejutkan bahwa langkah-langkah yang dilakukan AEC dalam Cetak Biru AEC menyepakati empat karakteristik yaitu pasar tunggal (single market) ${ }^{5}$ dan basis produksi, kawasan ekonomi yang berdaya saing tinggi, kawasan dengan pembangunan ekonomi yang setara, kawasan yang terintegrasi ke dalam ekonomi global. ${ }^{6}$ Dalam empat karakteristik tersebut memiliki kaitan erat dan saling memperkuat satu sama lain dan diupayakan untuk menciptakan kawasan yang berdaya saing tinggi, kesenjangan pembangunan antar negara anggota harus diperkecil sehingga setiap individu negara anggota ASEAN memiliki tingkat perkembangan ekonomi yang setara.

Tidak ketinggalan Indonesia harus ikut aktif dan berperan dalam AEC dan bisa meningkatkan daya saing dan mengejar ketertinggalan dari negara anggota ASEAN lainnya. Untuk itu, diperlukan suatu langkah-langkah strategis, di antaranya:Penyesuaian, persiapan dan perbaikan regulasi baik secara kolektif maupun individual (reformasi regulasi);Peningkatan kualitas sumber daya manusia baik dalam birokrasi maupun dunia usaha ataupun profesional;Penguatan posisi usaha skala menegah, kecil, dan usaha pada umumnya;Penguatan kemitraan antara sektor publik dan swasta;Menciptakan iklim usaha yang kondusif dan mengurangi ekonomi biaya tinggi, yang juga merupakan tujuan utama pemerintah dalam program reformasi komprehensif di berbagai bidang seperti perpajakan, kepabeanan, dan birokrasi;Pengembangan sektor-sektor prioritas yang berdampak luas dan komoditi unggulan;Peningkatan partisipasi institusi pemerintah maupun swasta untuk mengimplementasikan AEC Blueprint;Reformasi kelembagaan dan kepemerintahan. Pada hakikatnya AEC Blueprint juga merupakan program reformasi bersama yang dapat dijadikan referensi bagi reformasi di Negara Anggota ASEAN termasuk Indonesia;Penyediaan kelembagaan dan permodalan yang mudah diakses oleh pelaku usaha dari berbagai

${ }^{5}$ M.Sabir, “ASEAN, Harapan, \& Kenyataan”, Jakarta: Pustaka Sinar Harapan, 1992, hal.18

${ }^{6}$ Op.cit, hal 54 
skala;Perbaikan infrastruktur fisik melalui pembangunan atau perbaikan infrastruktur seperti transportasi, telekomunikasi, jalan tol, pelabuhan, revitalisasi, dan restrukturisasi industri. ${ }^{7}$

Tetapi pada dasarnya Pemerintah seharusnya mempersiapkan sumber daya manusia yang seharusnya bisa bersaing dalam persaingan global di Komunitas Ekonomi ASEAN tersebut. Diharuskan adanya pelatihan kerja yang menunjang di tiap-tiap daerah maupun kota dan juga sertifikasi yang mempunyai standar kerja berkualitas dari Pemerintah agar dapat bersaing di Komunitas Ekonomi ASEAN tersebut. Hal ini sebagai usaha nyata Indonesia dalam kesiapannya di Era Asean Economic Community itu sendiri.

\section{B. Kerangka Teori}

Teori yang digunakan untuk menganalisa permasalahan yang dibahas maka penulis menggunakan 2 (dua) teori yaitu:

\section{Teori Kepentingan Nasional}

Menurut Morgenthau, Kepentingan Nasional adalah kemampuan minimum negara untuk melindungi, dan mempertahankan identitas fisik, politik, dan kultur dari gangguan negara lain. Dari tinjauan ini para pemimpin negara menerapkan kebijakan spesifik terhadap negara lain yang sifatnya kerjasama atau konflik ${ }^{8}$.

Lain hal dengan Daniel S. Papp yang mengatakan bahwa dalam kepentingan nasional terdapat beberapa aspek, seperti ekonomi, ideologi, kekuatan dan keamanan militer, moralitas dan legalitas. Dalam hal ini, yang mana faktor ekonomi pada setiap kebijakan yang diambil oleh suatu Negara selalu berusaha untuk meningkatkanperekonomian Negara yang dinilai sebagai suatu kepentingan nasional.Suatu kepentingan nasional dalam aspek ekonomi diantaranya adalah untuk meningkatkan keseimbangan

${ }^{7}$ Diakses dari http://www.setneg.go.id/index.php?option=com_content\&task=view\&id=7911 tanggal 13 Oktober 2015

${ }^{8}$ H.J. Morgenthau, In Defense of the National Interest: A Critical Examination of American Foreign Policy, New York: University Press of America, 1951, hal 90 
kerjasama perdagangan suatu Negara dalam memperkuat sektor industri, dan sebagainya ${ }^{9}$.

Dalam rangka mencapai kepentingan nasional dilihat dari pembagian jenis kepentingan, maka kepentingan Indonesia dalam persiapan untuk menghadapi Masyarakat Ekonomi ASEAN lebih menitikberatkan pada kesiapan Indonesia dalam persaingan untuk mendapatkan kepentingan ekonomi yang berbasis pasar tunggal dan lainnya.

\section{Teori Kompetisi}

Michael E. Porter dalam bukunya mengenai Competitive Advantage menyatakan bahwa

"competitors are not equally attractive or not attractive. a good competitor is one can that perform the beneficial functions described aboved without representing to severe long-term threat. a good competitors is that one challenges the firm not to be complacent but is a competitor with wich the firm can achieve a stable and profitable industry equilibrium without protacted warfare."10

Didalam teori persaingan kita mengenal ada suatu teori dari Michael Porter yang sangat terkenal pada saat menganalisis persaingan atau competition analysis.Teori tersebut lebih dikenal dengan istilah Porter Five Forces Model.Intinya sebenarnya Porter menilai bahwa perusahaan secara nyata tidak hanya bersaing dengan perusahaan yang ada dalam industri saat ini. Kita biasanya hanya menganalisis siapa pesaing langsung kita dan akhirnya kita terjebak dalam "competitor oriented", sehingga tidak mempunyai visi pasar yang jelas. Dalam five forcesmodel digambarkan bahwa kita juga bersaing dengan pesaing potensial kita, yaitu mereka yang akan masuk, para pemasok atau suplier,para pembeli atau konsumen, dan

\footnotetext{
${ }^{9}$ D.S. Papp , "Contemporary International Relation": A Framework for Understanding, Second Editions. New York: MacMillan Publishing Company, 1988, hal.29

${ }^{10}$ Michael E. Porter, "Competitive Advantage: Creating and Sustaining Performance", The Free Press, New York, 1985 hal. 201
} 
produsen produk-produk pengganti. Dengan demikian.kita harus mengetahui bahwa ada lima kekuatan yg menentukan karakteristik suatu industri yaitu intensitas persaingan antar pemain yang ada saat ini, ancaman masuk pendatang baru, kekuatan tawar menawar pemasok, kekuatan tawar pembeli, dan ancaman produk pengganti. ${ }^{11}$

\section{Pokok Masalah}

Berdasarkan latar belakang permasalahan dan identifikasi masalah yang telah dijelaskan di atas, maka pokok permasalahan yang akan dibahas dalam penulisan ini adalah " BagaimanaKesiapan Indonesia Dalam Menghadapi Persaingan di Era Asean Economic Community".

\section{Tujuan Penelitian}

Tulisan tentang Indonesia Dalam Persaingan di Era Komunitas Ekonomi Asean mempunyai urgensi sebagai berikut : bahwa persiapan yang yang dilakukan Indonesia seharusnya mempunyai daya dampak yang sistemik terhadap pertumbuhan ekonomi Indonesia. Selain itu hendaknya sosialisasi yang sudah dilakukan ini terus dan tetap digelorakan oleh setiap anak bangsa agar tidak kalah bersaing dan ditelan oleh eksistensi Negaranegara kawasan yang benar-benar memanfaatkan AEC sebagai peluang ekonomi yang positif dan konstruktif bagi setiap Negara anggota ASEAN tentunya.

Penelitian yang berjudul "Indonesia dan Persaiangan Di Era Asean Economic Community "yang penulis angkat memiliki beberapa tujuan,antara lain:

1. Untuk mengetahui bentuk Komunitas Ekonomi ASEAN

2. Untuk Mengetahui manfaat dari Komunitas Ekonomi ASEAN

3. Untuk Mengetahui dari dampak dan peluang Indonesia dalam Komunitas Ekonomi ASEAN,

4. Untuk mengetahui strategi pembangunan sumber daya manusia Indonesia dalam persaingan di Komunitas Ekonomi ASEAN. 


\section{E. Metode Peneltian}

Metode penelitian yang digunakan dalam penulisan ini adalah deskriptif analisis yang menggambarkan fenomena sosial serta melukiskan realita sosial dan memaparkan permasalahan secara sistematis, faktual dan akurat mengenai fakta-fakta, sifat-sifat serta hubungan antara fenomena yang diselidiki. ${ }^{12}$

Dalam pengumpulan data, teknik yang digunakan adalah studi kepustakaan (Library Research), yang mana penulis berupaya mengumpulkan berbagai referensi yang korelatif dengan masalah yang diteliti, kemudian membandingkannya dan menyeleksinya ${ }^{13}$

Penelitian ini menggunakan metode deduktif yang menganlisa data dari pengetahuan yang bersifat umum menjadi khusus.Analisa ini bertujuan untuk mendeskripsikan permasalahan serta fenomena yang terjadi dan kemudian hasil penelitian data-data yang diperoleh dapat memberikan dukungan terhadap teori yang digunakan. ${ }^{14}$

HASIL DAN PEMBAHASAN EKSISTENSI KOMUNITAS EKONOMI ASEAN DAN Kesiapan Indonesia dalam Persaingan

\section{A. Cetak Biru Komunitas Ekonomi ASEAN}

Menjelang abad ke-21, ASEAN bersepakat untuk mengembangkan suatu kawasan yang terintegrasi dengan membentuk suatu komunitas negaranegara Asia tenggara yang terbuka, damai, stabil, dan sejahtera, saling peduli, dan diikat bersama dalam kemitraan yang dinamis.Upaya kesepakatan pembentukan Kommunitas ASEAN semakin kuat dengan ditandatanginya Deklarasi Cebu mengenai percepatan Pembentukan Komunitas ASEAN pada tahun 2015 (Cebu Declaration on the Acceleration

\footnotetext{
${ }^{12}$ Moh. Nazir, Metode Penelitian, Ghalia Indo, Jakarta, 1998, hal 63-64.

${ }^{13}$ Sumadi Suryabrata, Metode Penelitian, Cv Rajawali, Jakarta, 1989, hal 92-93

${ }^{14}$ Dr.Irawan Soehartono, Metode Penelitian Sosial, PT Remaja Rosdakarya, Bandung, 2002, hal.93
} 
of the Establishmant of an ASEAN Community by 2015) oleh para Pemimpin ASEAN pada KTT ke-12 di Cebu, Filipina. Para Pemimpin ASEAN menyepakati percepatan pembentukan komunitas ASEAN dari tahun 2020 menjadi tahun $2015 .^{15}$

\section{Isi Cetak Biru Komunitas Ekonomi ASEAN}

Cetak Biru Komunitas Ekonomi ASEAN memiliki 4 (empat) karakteristik utama, yakni untuk mewujudkan ASEAN sebagai ${ }^{16}$ : 1.Pasar tunggal dan basis produksi, dengan 5 (lima) elemen utama yaitu: (i) aliran bebas uang, (ii) aliran bebas jasa, (iii) aliran bebas investasi, (iv) aliran bebas tenaga kerja terampil, (v) aliran modal yang lebih bebas. Disamping kelima elemen tersebut, pasar tunggal dan basis produksi juga mencakup 2 (dua) komponen penting lainnya, yaitu Sektor Integrasi Prioritas (Sectors Integration Priority/PIS) dan kerjasama di bidang pangan, pertanian, dan kehutanan. 2. Kawasan ekonomi yang berdaya saing tinggi, dengan 6 (enam) elemen utama yaitu: (i) kebijakan persaingan usaha, (ii) perlindungan konsumen, (iii) hak atas kekayaan intelektual (HKI), (iv) pembangunan infrastruktur, (v) perpajakan, dan (vi) e-commerce. 3. Kawasan dengan pembangunan ekonomi yang setara, dengan 2 (dua) elemen utama yaitu: (i) pembangunan usaha kecil dan menengah (UKM), dan (ii) inisiatif integrasi ASEAN ( Inisiative for ASEAN Integration/IAI). 4. Kawasan yang terintegrasi ke dalam ekonomi global, dengan 2 (dua) elemen utama yaitu: (i) pendekatan terpadu terhadap ekonomi di luar kawasan, dan (ii) peningkatan partisipasi dalam jaringan pasokan global.

Keempat karakteristik diatas memiliki kaitan erat dan saling memperkuat satu sama lain. Untuk mewujudkan ASEAN sebagai pasar tunggal dan basis produksi, ASEAN harus memiliki daya saing ekonomi yang tinggi, baik secara individu antar negara anggota maupun sebagai kawasan dalam persaingan dengan kawasan atau negara lain. Untuk menciptakan kawasan yang

${ }^{15}$ Opcit, ASEAN Selayang Pandang, hal 2-5 
berdaya saing tinggi, kesenjangan pembangunan antar negara anggota harus diperkecil sehingga tiap individu negara anggota ASEAN memiliki tingkat perkembangan ekonomi yang setara.Pencapaian atas ketiga hal tersebut sangat diperlukan untuk menjadikan ASEAN sebagai kawasan yang siap terintegrasi secara penuh ke dalam ekonomi global. ${ }^{17}$

\section{Scorecard ASEAN Economic Community}

Cetak Biru Komunitas Ekonomi ASEAN merupakan rancang utama (master plan) untuk membentuk Komunitas ASEAN tahun 2015 dengan mengidentifikasi langkah-langkah integrasi ekonomi yang akan ditempuh melalui implementasi berbagai komitmen yang rinci dengan sasaran dan jangka waktu yang jelas. Dalam kaitan ini, ASEAN telah mengembangkan mekanisme Scorecard sebagai alat untuk mengukur tingkat implementasi komitmen ekonomi ASEAN dan alat komunikasi dengan para pemilik kepentingan.Scorecard memberikan gambaran komprehensif mengenai kemajuan ASEAN dalam mengimplementasikan Cetak Biru Komunitas Ekonomi ASEAN. Negara-negara ASEAN telah menyepakati 4 bentuk AEC Scorecard, yaitu untuk Kepala Negara/Pemerintah, Menteri, Pejabat Senior, dan Masyarakat Umum.

Proses penyempurnaan scorecard hingga saat ini masih terus dilakukan oleh ASEAN bekerjasama dengan Institut Penelitian Ekonomi untuk ASEAN dan Asia Timur (Economic Research Institute for ASEAN and East Asia/ERIA), sebuah lembaga riset yang membantu ASEAN dalam mempromosikan integrasi ekonomi ASEAN dan integrasi ekonomi Asia Timur yang lebih luas.

Cetak Biru Komunitas Ekonomi ASEAN juga memuat pedoman umum yang dituangkan dalam jadwal strategis, yakni tahapan pencapaian dari masing-masing karakteristik utama KEA, Untuk membentuk Komunitas Ekonomi ASEAN, ASEAN wajib melaksanakan kebijakan sesuai dengan

${ }^{17}$ Ibid, hal 55 
prinsip-prinsip ekonomi yang terbuka (open), yang berwawasan ke luar (ourward-looking), inklusif (inclusive), dan berorientasi pada pasar (marketdriven) sesuai dengan aturan-autran multilateral serta memperhatikan perbedaan tingkat pembangunan dan kesiapan masing-masing negara anggota ASEAN melalui penerapan formulasi ASEAN minus $X$. Selain itu, ASEAN harus patuh terhadap sistem berdasarkan aturan hukum (rules-based system) agar pemenuhan dan impelentasi komitmen-komitmen ekonomi dapat berjalan efektif.

Keempat pilar Cetak Biru saling berkaitan dan mendukung satu sama lain. ASEAN sebagai pasar tunggal dan basis produksi internasional harus memiliki daya saing ekonomi yang tinggi, baik sebagai kawasan dalam kerangka persaingan dengan kawasan/negara lain, maupun antar individu anggota.Untuk itu, kesenjangan pembangunan ekonomi antarnegara anggota menjadi setara.Hal ini perlu dilakukan mengingat globalisasi dapat memperbesar kesenjangan pembangunan secara potensial dapat menciptakan kerenggangan dan memperlemah solidaritas ASEAN. Manfaat integrasi yang dirasakan oleh seluruh anggota akan menjamin integrasi ekonomi yang berkelanjutan. Sebagai basis produksi internasional, maka pasar ASEAN yang terintegrasi secara penuh dengan pasar global menuntut pula koordinasi kebijakan eksternal antara negara anggota ASEAN.

Keterkaitan keempat pilar membutuhkan koordinasi, konsistensi dan kesatuan arah elemen-elemen dari setiap pilar, dimulai dari perencanaan sampai dengan tahap implementasi. Untuk menjamin hal tersebut maka keempat pilar perlu di dukung oleh riset, capacitybuilding dan efektivitas kelembagaan ASEAN, serta komitmen kuat tiap negara.

Khusus untuk pencapaian pilar pasar tunggal dan kesatuan basis produksi yang menjadi pokok dari bahasan digunakan untuk pencapaiannya juga terkait erat dan saling mendukung antara satu dengan lainnya. Dalam kerangka pasar tunggal ASEAN, aliran barang dan jasa yang bebas di kawasan akan mendorong efesiensi produki kawasan dalam kerangka supply 
chain. Kondisi tersebut akan membuka peluang lebih besar investasi lintas batas dalam kawasan. Aliran bebas investasi akan membutuhkan aliran bebas tenaga kerja dan aliran modal yang lebih bebas, sebagai faktor produksi. Sebaliknya, aliran bebas investasi akan meningkatkan arus barang dan jasa yang digunakan sebagai bahan baku maupun produk akhir.

Secara teknis pencapaian AEC 2015 menggunakan mekanisme dan inisiatif yang telah dibentuk oleh ASEAN selama ini yang diperkuat dengan penguatan institusi dalam kerjasama ASEAN. Masing-masing institusi dan inisiatif yang terlibat sebagai contoh adalah aliran bebas barang, inisiatif penurunan tarif dan non-tarif serta fasilitasi perdagangan menuju aliran bebas barang AEC 2015 di dasarkan pada perkembangan dan penyempurnaan mekanisme yang ada mulai dari Prefential Tarrif Arrangement (PTA), ASEAN Free Trade Area dan dilanjutkan oleh konsep cetak biru AEC. Hal yang sama juga terjadi untuk elemen-elemen lainnya di dalam pilar ini.

\section{Indonesia dan Masalah Implementasi Cetak Biru Komunitas Ekonomi ASEAN}

Permasalahan yang dihadapi Indonesia dalam implementasi komitmen Cetak Biru Komunitas Ekonomi ASEAN periode 2008-2009 antara lain banyaknya persetujuan yang belum di ratifikasi, kurang konsistennya Pemerintah RI dalam pemenuhan berbagai komitmen, dan masih banyak komitmen yang tertuang dalam Inpres Nomor 5 tahun 2008.

Pada akhir Mei 2010, Pemerintah RI menerbitkan Inpres baru mengenai Koordinasi Pelaksanaan Komitmen Cetak Biru Komunitas Ekonomi ASEAN periode 2010-2011 sebagai kelanjutan dari Inpres Nomor 5/2008 tentang Fokus Program Ekonomi Periode 2008-2009 yang telah habis masa berlakunya pada akhir 2009.Penerbitan Inpres fase ke-2 tersebut dimaksudkan untuk melihat sejauh mana Indonesia mengimplementasikan langkah-langkah (action lines) yang diamanatkan AEC Blueprint pada periode 2010-2011. 
Indonesia telah melahirkan regulasi penting yaitu UU No 7 Tahun $2014^{18}$ tentang Perdagangan yang telah diperkenalkan ke masyarakat sebagai salah satu strategi Indonesia membendung membanjirnya produk impor masuk ke Indonesia. UU ini antara lain mengatur ketentuan umum tentang perijinan bagi pelaku usaha yang terlibat dalam kegiatan perdagangan agar menggunakan bahasa Indonesia didalam pelabelan, dan peningkatan penggunaan produk dalam negeri. Melalui UU ini pula pemerintah diwajibkan mengendalikan ketersediaan bahan kebutuhan pokok bagi seluruh wilayah Indonesia Kemudian menentukan larangan atau pembatasan barang dan jasa untuk kepentingan nasional misalnya untuk melindungi keamanan nasional.Regulasi tersebut terasa penting bila mempertimbangkan kondisi perdagangan Indonesia selama ini belum optimal memanfaatkan potensi pasar ASEAN. Pada periode Januari-Agustus 2013 misalnya, ekspor Indonesia ke pasar ASEAN baru mencapai $23 \%$ dari nilai total ekspor Hal ini antara lain karena tujuan ekspor Indonesia masih terfokus pada pasar tradisional seperti Amerika Serikat, Tiongkok dan Jepang. Tingkat utilitisasi preferensi tarif ASEAN yang digunakan eksportir Indonesia untuk penetrasi ke pasar ASEAN baru mencapai 34,4\%. ${ }^{19}$

Penerbitan Inpres merupakan keseriusan Pemerintah Indonesia untuk melaksanakan komitmen dalam Cetak Biru Komunitas Ekonomi ASEAN sesuai dengan jadwal strategis yang telah ditetapkan.Namun demikian, rendahnya capaian scorecard Indonesia harus mendapatkan perhatian yang lebih serius, khususnya dari instasi-instasi teknis hingga saat ini belum menindaklanjuti langkah-langkah (action lines) yang menjadi ruang lingkup tugasnya.

Upaya serius yang sudah dilakukan Indonesia dalam ini secara teori kepentingan nasional sudah mencakup dan dapat dijadikan pijakan betapa

\footnotetext{
${ }^{18}$ Lihat UU No 7 tahun 2014 tentang Perdagangan

${ }^{19}$ Diakses dari http://berkas.dpr.go.id/pengkajian/files/info_singkat/Info\%20Singkat-VI-10-II-P3DI-April-2014-4.pdf tanggal 30 Desember 2014
} 
Indoensia sangat memperhatikan betul tentang ASEAN Economic Community selama ini.

\section{B. Manfaat ASEAN Economic Community Untuk Anggota ASEAN}

ASEAN Economic Community (AEC) merupakan sebuah peluang bagi negara anggota ASEAN karenanya liberalisasi perdagangan dan jasa merupakan sebuah peluang untuk mendapatkan peluang utnuk meningkatkan pertumbuhan ekonomi negara-negara di ASEAN.Dalam pemanfaatan peluang AEC beberapa negara ASEAN telah mempersiapkan berbagai upaya untuk membuat AEC 2015 dan tahun-tahun berikutnya sebagai kompetisi yang adil dan mensejahterakan negara-negara di ASEAN.

Untuk itu negara-negara di ASEAN telah menyepakati ASEAN Trade in Goods Agreement (ATIGA) pada pertemuan KTT ke 14 tanggal 27 Februari 2009.di Cha'am, Thailand. Lalu dengan perjanjian ATIGA tersebut diharapkan anggota-anggota ASEAN untuk mendapatkan beberapa manfaat seperti:

1. Penurunan dan penghapusan tarif yang telah di sesuaikan dengan the Roadmap for Integration of ASEAN (RIA) yaitu pada tahun 2010 untuk ASEAN-6 dan tahun 2015 untuk CLMV (Cambodia, Laos, Myanmar, Vietnam.

2. Penghapusan non-Tariff Barriers, merupakan suatu manfaat yang didapatkan oleh anggota ASEAN karena untuk mewujudkan integrasi kawasan ekonomi sesuai dengan ASEAN on Protocol on Notification.

3. Trade Facilitation, dengan adanya fasilitas perdagangan ini diharapkan seluruh anggota ASEAN akan tercipta suatu lingkungan yang konsisten, transparan, serta dapat diprediksi dalam transaksi perdagangan internasional sehingga dapat meningkatkan perdagangan dan kegiatan usaha kecil dan menengah (UKM), serta menghemat waktu dan mengurangi biaya transaksi. 
4. Arus bebas jasa, pada dasarnya menghilangkan hambatanhambatan perdagangan jasa yang terkait dengan pembukaan akses pasar (market acces)

5. Arus bebas investasi atau penanaman modal asing (PMA) juga diharapkan akan akan meningkatkan dalam hal penanaman modal baik dari dalam ASEAN maupun dari luar ASEAN, karena dengan penanaman modal asing akan meningkatkan tingkat kesejahteraan warga ASEAN.

6. Arus bebas modal, untuk mendukung transaksi keuangan yang lebih efisien, sebagai salah satu sumber pembiayaan pembangunan, memfasilitasi perdangan internasional, mendukung pengembangan sektor keuangan, dan meningkatkan sektor ekonomi.

7. Arus bebas tenaga kerja terampil, akan membuka seluas-luasnya lapangan kerja bagi seluruh warga ASEAN, para warga negara ASEAN dapat keluar masuk di kawasan ASEAN tanpa hambatan yang dituju.

Dari beberapa manfaat yang disebutkan sudah jelas bahwa pemanfaatan yang sudah disebutkan akan dilakukan tiap-tiap negara di ASEAN untuk mendapatkan keuntungan besar dari terbukanya ASEAN Economic Community. Oleh karena itu ASEAN sebagai organisasi regional sudah sepantasnya mengembangkan perluasan kerjasama dalam hal meningkatkan ekonomi para Anggota ASEAN yang telah berkomitmen dalam membangun kawasan ini.

\section{Kesiapan Indonesia Dalam Persaingan di era Asean Economic Community \\ Tidak dapat dipungkiri bahwa kawasan Asia Tenggara merupakan pasar potensial yang jumlah penduduknya sudah mencapai sekitar 650 juta orang, dengan tingkat pertumbuhan terus meningkatdari tahun 2015 hingga}


mencapai 2,3 persen ${ }^{20}$. Pada periode yang sama nilai Produk Domestik Bruto (PDB) tercatat senilai USD 1,1 triliun sehingga PDB perkapita mencapai USD 1.890. Nilai PDB tersebut dicapai dengan pertumbuhan 5,7 persen dengan prospek pertumbuhan yang menjanjikan. Dari sisi penduduk, 80 persen penduduk ASEAN terdiri dari usia di bawah 44 tahun.

Beberapa peluang yang bisa didapatkan Indonesia dalam menghadapi ASEAN Economic Community yaitu:

\section{Pasar Potensial}

Perwujudan AEC 2015 menempatkan ASEAN sebagai kawasan pasar terbesar ketiga di dunia yang di dukung oleh jumlah penduduk ketiga terbesar setelah China dan India. Hal ini akan memungkinkan arus barang dan jasa dari luar ASEAN pun akan ikut berkecimpung bersama peroduk-produk dari Negara ASEAN lainnya. Masyarakat dunia akan mudah untuk 'menggelontorkan ' uangnya terhadap regional ASEAN khususnya Indonesia.

\section{Negara Pengekspor.}

Dengan meningkatnya harga komoditas internasional, sebagian besar negara ASEAN mencatat surplus pada neraca transaksi berjalan.Prospek perekonomian yang cukup baik menyebabkan ASEAN menjadi tempat tujuan investasi.

\section{Negara Tujuan Investor.}

Kesempatan emas sebagai Negara tujuan investor semenjak di implementasikan tahun 2015 yang mana berbagai kerja sama regional untuk meningkatkan infrastruktur ( pipa gas, teknologi informasi ) maupun dari sisi pembiayaan menjadi agenda nasional. Kesempatan tersebut membuka peluang bagi perbaikan iklim investasi Indonesia.Terutama dalam melancarkan program infrastruktur domestik.

\section{Daya Saing.}

${ }^{20}$ R.Winantyo, dkk," Masyarakat Ekonomi ASEAN 2015 Memperkuat Sinergi ASEAN di Tengah Kompetisi Global”, Komputindo Kompas Gramedia, Jakarta, 2009, hal.286 
Liberalisasi perdagangan barang ASEAN akan menjamin kelancaran arus barang untuk pasokan bahan baku maupun bahan jadi di kawasan ASEAN karena hambatan tarif dan non tarif yang tidak ada lagi. Pembentukan ASEAN Economic Community ini diharapkan akan menjadi dasar bagi perdagangan barang, jasa, investasi, teknologi, dan sumber daya manusia antarnegara ASEAN ${ }^{21}$. Kemudian kerjasama ini diharapkan mampu mengatasi perbedaan setiap negara dengan membawa pertumbuhan ekonomi ASEAN ke arah yang lebih baik.Dalam kacamata neoliberal institusional, kerjasama ini terbentuk karena dua hal yakni mutual interest dan instutusional degree. Adanya kesamaan kepentingan diantara negara-negara di Asia Tenggara ini dalam pengembangan ekonomi membuat suatu kerjasama ini menjadi sebuah pembangunan yang didukung dengan rasa kepercayaan (trust) dan melalui institusi inilah ASEAN dengan ASEAN Economic Community-nya mencoba bersama-sama meningkatkan kualitas ekonomi diantara negara-negara Asia Tenggara.

\section{Sektor Jasa yang Terbuka.}

Sektor - sektor jasa yang telah di tetapkan yaitu pariwisata, kesehatan, penerbangan,logistic dan lainnya yang bagi Indonesia inipun menjadi peluang besar tentunya. Cetak biru AEC 2015 menyebutkan bahwa liberalisasi sektor jasa dimaksudkan untuk menghilangkan hambatan penyediaan jasa oleh pemasok ataupun pendirian jasa baru lintas negara di kawasan ASEAN dengan tetap tunduk pada regulasi domestik. Mekanisme perundingan liberalisasi jasa termasuk jasa keuangan dilakukan melalui AFAS (ASEAN Framework Agreement on Services).

\section{Aliran Modal.}

Dari sisi penarikan aliran modal asing, ASEAN sebagai kawasan dikenal sebagai tujuan penanaman modal global, sebagai suatu kawasan

${ }^{21}$ Bambang Cipto, "ASEAN Economic Community", dalam Hubungan Internasional di Asia Tenggara, Tropong Terhadap Dinamika, Realitas, Dan Masa Depan”, Pustaka Pelajar, Yogyakarta, 2007, hal 247 
merupakan pasar yang sangat potensial untuk dimanfaatkan dengan tingkat pertumbuhan yang terus meningkat.Ada beberapa poin yang harus menjadi perhatian serius dalam memahami mengapa interaksi ekonomi antara negara ASEAN masih lemah ${ }^{22}$.

Terkait dengan pemberlakuan AEC di tahun 2015, maka setiap komponen masyarakat harus proaktif dalam kerangka memperkuat ketahanan ekonomi bangsa yang didukung oleh ketahanan ideologi, sosial budaya, politik dan pertahanan dan keamanan. Ruang lingkup ketahanan tersebut pada dasarnya juga telah diatur dalam beberapa klausul Cetak biru Politik-Keamanan Masyarakat ASEAN. maka sebagai bagian dari masyarakat sudah seharusnya mendorong lahirnya sifat-sifat atau karakter manusiawi, arif, religius, inovatif, tangguh, integritas, dan mandiri

Dengan demikian tantangan yang dihadapi oleh Indonesia dalam ASEAN Economic Community (AEC) tidak hanya dari dalam negeri saja tetapi yang lebih besar adalah persaingan dengan sesama negara ASEAN dan negara di luar ASEAN seperti India, Korea dan Cina. Tantangan yang besar bagi indonesia .Cukup rumit dan mengerutkan kening tentunya. Jika hanya bergelut di permasalahan tantangan yang dihadapi Indonesia, tentu ada peluang yang bisa kita tangkap dalam pelaksanaan ASEAN Economic Community diantaranya Indonesia akan dipacu lebih kompetitif dalam mencetak tenaga terampilnya. Tanpa tantangan kita tidak akan berkembang. Ini akan membuat semangat yang tidur akan terbangun. Bersaing dan bersaing.Indonesia harus optimis bahwa Indonesia juga tidak akan kalah dengan negara tetangga se Asia tenggara.

Pengelolaan industri maritim juga harus menjadi sorot utama dalam pengembangan industri. Kawasan Asia Tenggara menjadi pasar ekonomi yang sangat kompetitif dengan jaringan produksi dan distribusi yang saling terhubung.Karena itu, berbagai prioritas pembangunan industri perkapalan dan perbaikan fasilitas pelabuhan menjadi penting bagi setiap negara

${ }^{22}$ Jurnal Luar Negeri, Edisi Khusus II, Tahun 2011, hal 2-4 
anggota ASEAN, terutama negara kita, negara dengan luas laut sangat besar seperti Indonesia. Industri perkapalan akan menjadi prospek yang sangat cerah dimasa depan dan karna basic indonesia sebagai negara kelautan. Meminjam gambaran Tan Malaka akan kehebatan Indonesia dalam industry maritim" boleh saja Amerika bisa menaklukkan Dunia dan samudera dengan syarat Indonesia harus mampu diraihnya terlebih dahulu sebagi basis kekuasaannya .

Kepercayaan diri bangsa ini tidak boleh hilang dan tertelan oleh zaman, rakyat harus percaya pada kekuatan bangsa dan Negara ini, Negara ini kaya, modal yang kuat untuk bersaing.Terkait jumlah sumber daya dimiliki jumlah penduduk yang besar .Sumber daya alam dan manusia Indonesia berpotensi memberikan pengaruh besar bagi suksesnya ASEAN Economic Community. Indonesia memiliki kekayaan sumber daya alam yang cenderung lengkap ketimbang negara-negara ASEAN lain. Sejumlah komoditas utama di sektor pertanian dan pertambangan yang dibutuhkan ASEAN berasal dari Indonesia.Cengkeh, bawang, sayuran hingga komoditi lainnya semuanya ada negeri terberkahi ini.

Bangsa ini sudah punya pengalaman jungkir balik dalam mengatasi perekonomiannya. Pengalaman krisis moneter tahun 1998 menjadikan Indonesia jauh lebih bermental dan siap dalam mengarungi lautan ekonomi global. Pengalaman ini merupakan hal yang penting agar Indonesia tidak terlalu rapuh dimata kompetitor lainnya.Pemerintah harus sepenuh hati berbenah diri terhadap bangsa ini.Dari ancaman nyata menjadi sebuah kesempatan emas untuk membawa negeri ini ke arah yang lebih baik.Dengan persiapan yang matang, Indonesia bisa menjadi pemeran utama dalam kebijakan ini. Sepatutnya Indonesia yang mengawal dan Indonesia lah yang harus ditakuti oleh negara lain. Zona bahaya yang tadinya mengancam akan menjadi ladang emas sebagaimana penempatannya. Dengan meningkatkan aspek kreatifitas dan peningkatan kualitas produksi yang disebabkan dorongan untuk tetap eksis ditengah persaingan global, akan 
menghasilkan produk-produk dalam negeri yang handal dan berkualitas. SDM Indonesia akan berusaha meningkat kualitas baik hardskill ataupu softskillnya sehingga SDM indonesia akan semakin berkualitas. Kemampuan berinovasi akan terus diasah. Semangat yang tertidur akan dibangunkan oleh AEC 2015 lalu mestinya

Beberapa infrastruktur yang harus disiapkan Indonesia pada era AEC antara lain: darat, berupa jejaring jalan ASEAN dan jalur rel kereta KunmingSingapura; laut, berupa jejaring perhubungan laut; udara, berupa jalur pengiriman udara;teknologi informasi, berupa jaringan komunikasi; dan energi, berupa keamanan energi Beberapa infrastruktur yang telah dibangun, meliputi: penataan pelabuhan Tanjung Priok; pembangunan bandara internasional Lombok Praya dengan rute internasional Malaysia, Singapura, Australia, dan Hongkong ; Sabuk Selatan Nusantara yang menghubungkan 16 pulau dari Sabang sampai Merauke $(5.330 \mathrm{~km}$ jalan dan $1.600 \mathrm{~km}$ jalur laut) dan Sabuk Tengah Nusantara sepanjang $3.800 \mathrm{~km}$ yang menghubungkan 12 provinsi dari Sumatra Selatan hingga Papua Barat ${ }^{23}$.

Beberapa infrastruktur yang belum dibangun atau masih dalam tahap penyelesaian, yakni: Indonesia mengajukan perpanjangan jalur kereta Kunming-Singapura hingga ke Surabaya; rencana pembangunan Jembatan Selat Sunda (diproyeksikan rampung 2025); dan Sabuk Utara Nusantara rampung pada 2015.

Bahwa pembangunan infrastruktur yang rendah di Indonesia, dipengaruhi oleh beberapa faktor penghambat, yakni:

1. Anggaran infrastruktur yang rendah, hanya $2,5 \%$ dari PDB, dimana jumlah ini tidak dapat mengakomodir biaya pembebasan lahan dan

${ }^{23}$ Diakses dari http://www.setneg.go.id/index.php?option=com content\&task=view\&id=7911 tanggal 28 Desember 2014 
biaya feasibility study serta AMDAL yang kerap muncul dalam pembangunan infrastruktur.

2. Konflik kepentingan, seperti politik, bisnis, atau pesanan pihak-pihak tertentu dalam pembangunan infrastruktur.

3. Koordinasi yang sulit, jika merujuk area pembangunan infrastruktur terkait dengan hutan lindung atau pertanian dimana koordinasi antara lintas kementerian dan lintas otoritas sulit dilakukan.

Dampak dari rendahnya infrastruktur berpengaruh pada semakin mahalnya biaya logistik di Indonesia. Perdagangan menjadi kurang efisien mengingat biaya logistik yang mahal dibandingkan negara anggota ASEAN lainnya, yang dibebankan sebesar $14,08 \%$, jika dibandingkan dengan biaya logistik yang wajar sebesar $7 \%$. Berdasarkan Logistic Performance Index ${ }^{24}$ (LPI, 2012), Indonesia menempati peringkat ke-59 dari 155 negara, di bawah peringkat Thailand, Filipina, dan Vietnam. Dengan pengurangan biaya logistik, maka permasalahan dalam bidang perdagangan diharapkan dapat teratasi sehingga menaikkan daya saing Indonesia.

Bonus demografi yang dimiliki Indonesia, tidak akan memberikan keuntungan apa pun tanpa adanya perbaikan kualitas SDM. Data dari ASEAN Productivity Organization (APO) menunjukkan dari 1000 tenaga kerja Indonesia hanya ada sekitar 4,3\% yang terampil, sedangkan Filipina 8,3\%, Malaysia $32,6 \%$, dan Singapura $34,7 \%$. Berdasarkan struktur pasar, tenaga kerja didominasi oleh pekerja lulusan SD (80\%) sementara lulusan Perguruan Tinggi hanya $7 \%$, dimana saat ini sebagian dunia kerja mensyaratkan lulusan Perguruan Tinggi. Hal ini sangat berbanding terbalik dengan Malaysia yang sebagian besar penduduknya lulusan $\mathrm{S} 1$.

Namun,rendahnya tingkat pendidikan pada $72 \%$ tenaga kerja Indonesia mengakibatkan sulitnya bagi kelompok masyarakat untuk

${ }^{24}$ Diakses dari http://lpi.worldbank.org/ tanggal 4 januari 2015 
mendapatkan pekerjaan formal dengan tingkat keterjaminan yang relatif lebih baik. Hanya sebagian kecil (8\%) dari komposisi tenaga kerja Indonesia yang berdaya saing, $3 \%$ di antaranya merupakan profesional dengan tingkat pendidikan minimal sarjana, sedangkan $5 \%$ di antaranya merupakan semiskilled worker dengan pendidikan diploma dan kejuruan. Potret itu tentunya menjadi kegelisahan yang cukup mengganggu dalam menyongsong pasar tunggal ASEAN ketika arus liberalisasi jasa termasuk jasa profesi baik skillful labor maupun semi-skilled labor.

Tugas pemerintah dan para pemangku kepentingan yang terkait ialah mempersiapkan sumber daya manusia unggul dan berdaya saing dengan memastikan pembangunan ekonomi linear dengan pembangunan manusia. Kualitas tenaga kerja yang tinggi akan hadir apabila kualitas pembangunan manusia Indonesia berdaya saing unggul. Akses terhadap pendidikan, kesehatan, pekerjaan, gizi, dan fasilitas publik lainnya akan menentukan kualitas manusia dan tenaga kerja Indonesia. Untuk itu, dapat ditarik kesimpulan bahwa pembangunan nasional harus dapat diarahkan ke peningkatan modal manusia (human capital).

Peningkatan modalitas manusia hanya dapat dicapai jika kesehatan dan pendidikan terpenuhi di atas kebutuhan minimal. Modal (sumber daya) manusia berkualitas merupakan mesin penggerak pertumbuhan ekonomi dan pembangunan secara keseluruhan karena berfungsi meningkatkan kapasitas pembangunan dan mempercepat program- program pembangunan (catalyst agent). Dengan demikian, logika pembangunan nasional perlu diluruskan ke upaya pembangunan sumber daya manusia untuk mencapai percepatan pembangunan dan pertumbuhan ekonomi.

Kesempatan memperoleh pendidikan secara merata di seluruh Indonesia sulit dilakukan sehingga kesadaran untuk menempuh pendidikan ke jenjang yang lebih tinggi sangat rendah.Kondisi ini mengakibatkan tenaga kerja Indonesia hanya dilirik sebagai buruh atau tenaga kerja kasar di pasar 
tenaga kerja internasional. Tindakan pemerintah untuk menopang komitmen Indonesia dalam AEC 2015 melalui penerbitan Peraturan Presiden Nomor 39 Tahun 2014 tentang Daftar Usaha yang Tertutup dan Bidang Usaha Terbuka dengan Persyaratan di Bidang Penanaman Modal, dipandang hanya akan memberikan keuntungan bagi pihak-pihak tertentu, bukan petani Indonesia. Perpres tersebut mengatur mengenai: 1. Investasi asing diperbolehkan hingga $49 \%$ untuk usaha budidaya tanaman pangan seluas lebih dari 25 hektar.

2. Investasi asing diperbolehkan hingga 95\% untuk usaha perkebunan dalam hal perbenihan bagi usaha seluas lebih dari 25 hektar.

3. Investasi asing diperbolehkan hingga $30 \%$ untuk usaha perbenihan dan budidaya hortikultura.

Melihat bahwa sektor pertanian masih tertinggal dan dibebani volume impor komoditas pangan dan hortikultura; kegagalan panen akibat kemarau dan gangguan hama; serta petani Indonesia rata-rata berusia 55-60 tahun dan tidak memiliki pengetahuan dan pendidikan yang memadai akan menyulitkan memasuki pasar bebas ASEAN. Indonesia dengan populasi luas kawasan dan ekonomi terbesar di ASEAN, dapat menggerakkan pemerintah untuk lebih tanggap terhadap kepentingan nasional, khususnya pertanian. Pemerintah perlu mengambil langkah-langkah:

1. Menghitung kesiapan dan daya dukung nasional dalam menghadapi pasar bebas ASEAN. Untuk itu Perpres No.39/2014 ${ }^{25}$ perlu dievaluasi mengingat sangat merugikan petani Indonesia.

2. Mendongkrak kapasitas produksi, kualitas pengetahuan dan permodalan agar Indonesia tidak bergantung pada impor.

${ }^{25}$ Lihat Perpres No. 39 Tahun 2014 tentang Daftar Bidang Usaha Yang Tertutup dan Bidang Usaha Yang Terbuka Dengan Persyaratan Di Bidang Penanaman Modal 
3. Menyiapkan perlindungan bagi petani dengan penetapan tarif maksimal untuk produk impor.

4. Menyediakan subsidi dan pengadaan kredit lunak bagi petani guna meningkatkan kemampuan mereka memasok kebutuhan pertanain seperti benih dan pupuk.

Secara teori kompetisi Indonesia memanfaatkan posisi tawarnya yang sangat besar untuk kepentingan nasional dalam kompetisi serius di komunitas ekonomi ini.Jika dilihat dari nilai Produk Domestik Bruto (PDB), Indonesia merupakan penyumbang terbesar (lebih dari sepertiga) PDB ASEAN yang mencapai1,2 triliun US\$ (PPP). Dari jumlah populasi ASEAN (600 juta orang), Indonesia merupakan negara dengan penduduk terbesar, yang pada tahun 2013 diperkirakan mencapai 250 juta.Sekitar 60persen di antaranya adalah kelas menengah dengan pertumbuhan relatif tinggi.

Selain potensi sumber daya manusia, ekonomi Indonesia juga didukung oleh sumber daya alam yang kaya dan beragam, serta wilayah yang sangat luas baik wilayah daratan maupun lautan.Berbagai faktor tersebut semestinya dapat dijadikan sebagai modal untuk meningkatkan posisi tawar Indonesia dalam berbagai kerjasama ekonomi.

Demikian juga dalam kerjasama MEA, seharusnya Indonesia dapat memanfaatkan posisi tawarnya untuk mendapatkan keuntungan maksima ${ }^{26}$ I saat ASEAN dijadikan sebagai pasar yang terintegrasi dan basis produksi yang kompetitif. Namun ada keraguan besar Indonesia akan dapat mewujudkan hal tersebut. Untuk kasus industri otomotif misalnya, Malaysia mampu membuat kesepakatan dengan industri otomotif Jepang, sehingga produk otomotif Jepang boleh masuk ke pasar Malaysia, tetapi dengan syarat menggunakan merek nasional Malaysia dan perencanaan jelas untuk pengalihan teknologi. Dengan kesepakatan kerjasama dan strategi

${ }^{26}$ Diakses dari http://disbun.jabarprov.go.id/index.php/artikel/detailartikel/46 tanggal 29 Desember 2014 
industrialisasi yang jelas, akhirnya Malaysia mampu membangun industri otomotif nasional dan bahkan dapat memasarkan produknya ke luar negeri.

Sedangkan Indonesia, meskipun posisi tawar lebih besar dibanding Malaysia, baik dari potensi pasar maupun faktor produksi, hingga saat ini Indonesia belum juga memiliki industri otomotif nasional.Di sektor jasa perbankan, Indonesia juga belum mampu memanfaatkan daya tarik pasar domestik dengan kebijakan yang dapat menguntungkan kepentingan nasional.

Indonesia telah membuka kepemilikan asing di bank lokal hingga 99 persen, aturan pembukaan cabang dan ATM tidak terbatas, serta segmen pasar bank asing yang tidak dibatasi.

Sementara Singapura yang memiliki sektor jasa keuangan dan perbankan yang jauh lebih kompetitif tetap membatasi kepemilikan asing di bank lokal maksimal hanya 20 persen, ijin operasional diberikan berjenjang dan pembukaan cabang dan ATM sangat terbatas. Demikian juga Malaysia dan Thailand yang memiliki kebijakan jelas dalam mendukung daya saing sektor perbankan dalam memanfaatkan pasar domestiknya.

Lemahnya posisi tawar Indonesia terutama disebabkan oleh tidak adanya strategi dan kebijakan industri yang komprehensif yang akan menjadi referensi bagi pemerintah. Bila ada acuan yang jelas maka pada setiap perundingan kerjasama ekonomi baik regional seperti MEA, kerjasama global seperti WTO maupun kerjasama-kerjasama bilateral, Indonesia akan memiliki langkah yang jelas dan konsisten. Strategi dan kebijakan industrialisasi nasional ini pula yang kemudian akan menjadi acuan bagi kesepakatan pemangkasan tarif bea masuk, membuka atau membatasi impor suatu produk.

\section{Strategi Indonesia Dalam Menghadapi ASEAN Economic Community}


Dalam Era ASEAN Ecomoic Community pemerintah Indonesia harus melakukan langkah-langkah strategis agar tidak menjadi negara pemasaran bagi produk-produk luar negeri sedangkan untuk investasi, negara lain lebih memilih untuk investasi, negara lain lebih memilih untuk investasi di negara pelaksanaan usahanya sudah meningkat di antaranya Thailand, Malaysia, Vietnam, dan Brunei Darussalam. Untuk itu pemerintah harus melakukan langkah strategis yang dapat dilakukan, diantaranya:

\section{Re- sosialisasi}

Upaya sosialisasi hajat besar AEC ini belum merata, hanya sebatas kalangan tertentu, bisa dibilang kalangan menegah ke atas. Sedangkan, masyarakat awam ke bawah tidak begitu mengenalnya. Jangankan bersiap, mengenalpun kurang. Kampanye mengenai AEC seharusnya tak kalah serunya dengan kampanye Pilkad Pileg bahkan Pemilu Presiden, dengan tim suksesnya yang melakukan sosialisasi dari poster hingga broadcast massage ke telepon genggam. Karena untuk sosialisasi tidak hanya di seminar ataupun ruang-ruang khusus yang sudah di tentukan, tetapi juga personal message yang bisa disampaikan untuk mengingatkan setidaknya dengan memberikan poin-poin khusus dalam pelaksanaan AEC tahun 2015 dan tahun-tahun selanjutnya.

\section{Pemberdayaan Usaha Mikro, Kecil, dan Menegah (UMKM)}

UMKM merupakan sektor ekonomi nasional yang sangat strategis dalam pembangunan ekonomi kerakyatan.Pemberdayaan ini dapat meciptakan iklim usaha dan mengurangi ekonomi biaya tinggi.Pemberdayaan UMKM sangat diperlukan untuk meningkatkan daya saing ekonomi ${ }^{27}$.Persaingan dalam hal kulaitas yang bukan hanya untuk pasar lokal dan nasional, tetapi juga ekspor.

${ }^{27}$ Dikutip dari UKM Merasa terancam Standar ASEAN, Kontan , Jumat 6 Mei 2011 
Semakin banyak UMKM yang bisa mengekspor, akan semakin besar pula daya saing ekonomi Indonesia. pelatihan penggunaan website dalam rangka memperluas segmentasi konsumen juga sangat diperlukan di era digital saat ini. Hal ini yang terkadang masih jarang dilakukan UMKM. Pemerintah, dalam hal ini Kementrian Perdagangan bekerja sama dengan pemerintah daerah dan lembaga/kementerian terkait akan memberikan dukungan penuh kepada para pengusaha dalam upaya menciptakan produk berdaya saing tinggi.Dikatakannya, diberlakukannya AEC mulai Desember 2015 bagi Indonesia bagai dua sisi mata uang. Di satu sisi, hal itu merupakan peluang bagi para pelaku usaha di Indonesia berekspansi ke wilayah ASEAN tanpa adanya hambatan. Namun di sisi lain kran akan terbuka luas bagi produk luar negeri masuk ke Indonesia.

Terkait kesiapan menjelang pemberlakuan Masyarakat Ekonomi ASEAN pada 2015 yang lalu Menteri Perindustrian M.S Hidayat mengatakan kesiapan Indonesia baru mencapai 81 persen.Capaian Indonesia pada fase ketiga tersebut menempati posisi ke-enam dari 10 anggota negara ASEAN.Menurut M.S Hidayat ${ }^{28}$, Indonesia harus lebih serius dalam menghadapi Masyarakat Ekonomi ASEAN. Ada 3 hal penting yang masih menjadi masalah serius di Indonesia, yaitu biaya produksi di Indonesia masih lebih mahal jika dibandingkan dengan negara ASEAN lainnya. Kedua yaitu permasalah infrastruktur dan terakhir mengenai kesiapan Indonesia di bidang jasa.

\section{Penyediaan Modal}

Permodalan ini sangat penting untuk meningkatkan kapasitas produksi suatu usaha.Oleh karenanya, dibutuhkan lembaga permodalan yang mudah diakses oleh pelaku usaha dari berbagai skala.Terutama pelaku UMKM yang seringkali kesulitan dalam penambahan modal.

${ }^{28}$ Dikutip dari MS.Hidayat, Media Indonesia, Jumat 29 April 2011 


\section{Peningkatan Kualitas Sumber Daya Manusia}

SDM merupakan hal yang paling krusial dalam era AEC, SDM yang berkualitas akan mampu bersaing dan kuat menghadapi tantangan. Inovatif dalam mengambil ide, langkah, dan tindakan adalah tujuan dari peningkatan kualitas SDM, serta peningkatan dengan pelatihan bahasa.Karena bagaimanapun bahasa sangat penting dalam persaingan global, terutama bahasa inggris.Pelatihan dan pengembangan kemampuan (skill) juga seharusnya lebih dilakukan, seperti workshop, pertemuan rutin antara pelaku ekonomi, juga pembangunan jaringan.Semua hal ini dilakukan agar pelaku ekonomi selalu mengikuti perkembangan terbaru perekonomian. Tindak lanjut dari semua solusi dari pelatihan hingga pengembangan adalah rencana strategis yang harus di utamakan dalam melakukan tindak lanjut kegiatan ekonomi di Indonesia, karena manusia yang berkualitas akan membuat produksi yang berkualitas juga. Sejumlah pimpinan asosiasi profesi sangat optimis bahwa tenaga kerja Indonesia dapat bersaing dalam di AEC. Ketua Persatuan Advokat Indonesia Otto Hasibuan ${ }^{29}$ mengatakan bahwa tren penggunaan pengacara asing di Indonesia mulai menurun, karena sudah banyak anggota-anggota sudah banyak yang kuliah di luar negeri, lalu juga dengan sektor Akuntan dari Ketua Institut Akuntan Publik Indonesia Tarko Sunaryo mengatakan bahwa ada ke khawatiran terhadap kaum pemuda yang belum menyadari tentang $\mathrm{AEC}$, namun kesiapan harus dilakukan dari mental sampai bahasa inggris.

\section{Perbaikan Infrastruktur}

Infrastruktur berupa sarana dan prasarana seperti logistik, litstrik, telekomunikasi, revitalisasi transportasi, jalan raya, rel kereta api, pelabuhan, bandara, dan lain-lain. Perbaikan harus disegerakan agar tidak menghambat

${ }^{29}$ Diakses dari http://www.bbc.co.uk/indonesia/berita indonesia/2014/08/140826 pasar tenaga kerja aec tanggal 3 januari 2014 
faktor distribusi, tersendatnya logistik dapat meningkatkan inflasi dan infrastruktur mempengaruhi sangat ditentukan cepat atau lambatnya keluar masuk barang.Upaya yang sedang dan akan terus dilakukan adalah memanfaatkan pelabuhan dan bandara berstatus internasional serta PT Penjaminan Infrastruktur Indonesia (PII) untuk meningkatkan promosi investasi di bidang infrastruktur. Selain itu, meningkatkan kerjasama infrastruktur dengan sektor swasta, meningkatkan anggaran dalam pembangunan infrastruktur dan pembangunan konektivitas antar provinsi, meningkatkan kerjasama subregional agar pembangunan infrastruktur tidak terkonsentrasi di Semenanjung Malaya dan Indochina.Juga, meningkatkan pasokan energi dan listrik agar dapat bersaing dengan negara yang memiliki infrastruktur yang lebih baik.

Pemerintah, akan mengoptimalisasi peran swasta dalam pengembangan infrastruktur, antara lain dengan cara implementasi Peraturan Presiden tentang Kerjasama Swasta dan Cetak Biru Sislognas. Cara lain adalah mengoptimalisasi efektivitas keberadaan PII untuk meningkatkan pembangunan infrastruktur di luar Pulau Jawa. Kedua, dalam upaya mendorong pengembangan industri nasional, pemerintah akan memberikaninsentif fiskal. Pemberian insentif fiskal dan tersebut seperti pembebasan Pajak Penghasilan badan untuk jangka waktu 5 sampai dengan 10 tahun serta tambahan pengurangan Pajak Penghasilan sebesar 50 persen selama dua tahun untuk industri pionir.

Ditambah lagi dengan investement allowance sebesar 30 persen dari nilai penanaman modal, percepatan penyusutan dan amortisasi yang dipercepat, pengurangan tauf PPh atas dividen luar negeri dan perpanjangan kompensasi kerugian bagi investasi di bidang usaha atau daerah dengan prioritas tinggi skala nasional. Ketiga, pengembangan Kawasan Ekonomi Khusus (KEK).Pengembangan KEK ini, merupakan bagian dari upaya untuk meningkatkan daya saing ekonomi menyongsong AEC 2015. 
Fungsi $\mathrm{KEK}^{30}$ adalah untuk melakukan dan mengembangkan usaha dibidang perdagangan, jasa, industri, pertambangan dan energi, transportasi, maritim dan perikanan, pos dan telekomunikasi, pariwisata dan bidang lain. Saat ini sudah terbentuk KEK di dua lokasi yakni di Tanjung Lesung, Banten, dan Sei Mangkei, Sumatera Utara sementara tiga KEK lainnya diharapkan dapat dibentuk pada 2014. Pengembangan KEK juga akan diberikan fasilitas insentif berupa fiskal dan non fiskal di sektor perpajakan, kepabeanan dan cukai. Investor akan mendapatkan keringanan pajak dan retribusi daerah, selain kemudahan administrasi pertanahan, perizinan, keimigrasian dan investasi.

Hal tersebut bertujuan untuk memberi kemudahan dalam memperoleh hak atas tanah sesuai dengan ketentuan peraturan perundangundangan.Fasilitas lainnya adalah kemudahan pengurusan perizinan melalui Pelayanan Terpadu Satu Pintu (PTSP) dan sektor ketenagakerjaan.Di sektor ketenagakerjaan, KEK diizinkan untuk memperkerjakan tenaga kerja asing (TKA) yang mempunyai jabatan sebagai direksi atau komisaris yang diberikan sekali dan berlaku selama TKA yang bersangkutan menjadi direksi atau komisaris.

Perlu disadari, bahwa infrastruktur di negeri kita masih jauh dari apa yang diharapkan. Masalah infrastruktur merupakan pekerjaan rumah ${ }^{31}$, adalah: 1) Memperbaiki semua infrastruktur yang rusak, seperti jalan-jalan raya yang berlubang dan bergelombang (sebagian hancur karena tanah longsor dalam waktu singkat); 2) Membangun jalan tol atau jalan kereta api ke pelabuhan, dan memperluas kapasitas pelabuhan seperti Tanjung Priok, Tanjung Perak dan lainnya yang selama ini menjadi pintu keluar masuk barang dalam beberapa tahun ke depan; 3) Meningkatkan akselerasilistrik dalam dua tahun ke depan, dan banyak lagi. Sangatlah penting untuk

${ }^{30}$ Diakses dari http://www.hukumonline.com/berita/baca/lt51d63934f0fb0/strategi-pemerintah-hadapi-aec-2015 ${ }^{31}$ Dikutip dari ASEAN Connectivity, Suara Karya, Selasa 5 April 2011 
mempermudah aliran logistik yang merupakan urat nadi perdagangan pada khususnya, seperti pengiriman hasil produksi dan logistik dari pabrik ke pelabuhan atau sebaliknya atau dari pelabuhan ke pusat pemasaran.Memerlukan sarana transportasi yang memadai, seperti kondisi jalan raya yang baik dan mencukupi, fasilitas pelabuhan yang memadahi dan lain-lain perlu penanganan yang serius dan terkoordinir. Tercapainya infrastruktur yang memadahi akan berpengaruh besar terhadap daya saing produk dalam negeri. Dengan demikian, daya saing sangat ditentukan oleh kecepatan barang masuk dan keluar.Saking pentingnya infrastruktur dalam mensukseskan AFTA 2015, Pemerintah seharusnya menjadikan sektor ini adalah sektor yang paling diprioritaskan.

\section{Reformasi Kelembagaan \& Pemerintah}

Kelembagaan dan pemerintah yang taat hukum \& tidak memihak sangat diharapkan.Sikap kelembagan \& Pemerintah yang kooperatif terhadap pelaku usaha merupakan salah satu hal yang harus diperbaiki.Tidak mempersulit urusan administrasi dan birokrasi yang berkepanjangan.Penguatan lembaga hukum harus ditingkatkan, terutama dalam hal independensi dan akuntabilitas kelembagaan hukum.Sehingga tercipta iklim kelembagaan yang profesional dan transparan.Upaya peningkatan kesejateraan kelembagaan \& pemerintah juga terus dilaksanakan guna mencegah tindakan yang mengarah dan berpotensi korupsi atau pungli.

\section{Reformasi Iklim Investasi}

Indonesia harus melakukan pembenahan iklim investasi melalui perbaikan infrastruktur ekonomi, menciptakan stabilitas makro ekonomi, serta adanya kepastian hukum dan kebijakan, dan memangkas ekonomi biaya tinggi. 


\section{PENUTUP}

Indonesia sebagai negara anggota ASEAN menghadapi ASEAN Economic Community dan berhubungan dengan Kepentingan Nasional sebuah Negara harus lebih siap dari Negara-negara anggota ASEAN lainnya dan ini dapat diartikan bahwa Indonesia sangat menjaga dan mempertahankan kepentingan nasional terhadap kebijakan ASEAN Economic Community dan persaingan dalam merebut pangsa pasar di ASEAN denagn berbagai macam strategi .

Dalam persiapannya Indonesia mempunyai strategi yaitu sosialisasi menyeluruh ke seluruh daerah dengan membuat seminar kepada murid, dosen, serta mahasiswa dan masyarakat setempat, dan juga memilih Duta Muda ASEAN dari kalangan mahasiswa/i; (2) Penyesuaian, persiapan dan perbaikan regulasi baik secara kolektif maupun individual (reformasi regulasi); (3) Peningkatan kualitas sumber daya manusia baik dalam birokrasi maupun dunia usaha ataupun profesional; Penguatan posisi usaha skala menegah, kecil, dan usaha pada umumnya; (4) Penguatan kemitraan antara sektor publik dan swasta; (5) Menciptakan iklim usaha yang kondusif dan mengurangi ekonomi biaya tinggi, yang juga merupakan tujuan utama pemerintah dalam program reformasi komprehensif di berbagai bidang seperti perpajakan, kepabeanan, dan birokrasi; (6) Pengembangan sektorsektor prioritas yang berdampak luas dan komoditi unggulan; (7) Peningkatan partisipasi institusi pemerintah maupun swasta untuk mengimplementasikan AEC Blueprint; (8) Reformasi kelembagaan dan kepemerintahan. Pada hakikatnya AEC Blueprint juga merupakan program reformasi bersama yang dapat dijadikan referensi bagi reformasi di Negara Anggota ASEAN termasuk Indonesia; (9) Penyediaan kelembagaan dan permodalan yang mudah diakses oleh pelaku usaha dari berbagai skala; (10) Perbaikan infrastruktur fisik melalui pembangunan atau perbaikan infrastruktur seperti transportasi, telekomunikasi, jalan tol, pelabuhan, revitalisasi, dan restrukturisasi industri. 
Persiapan Indonesia untuk saat ini telah mengikuti pertemuanpertemuan tentang regulasi/kebijakan dari ASEAN mengenai ASEAN Economic Community, dan juga dari pembahasan strategi , dalam sosialisasi serta seminar-seminar dilakukan, serta pelatihan terhadap para pekerja dalam persaingan di AEC tahun 2015, serta penguatan dan usaha kecil menengah dalam berkompetisi di AEC.

Kendala Indonesia dalam menghadapi AEC adalah birokarsi pemerintahan yang menyulitkan membuat kepada para pengusaha kecil dan menengah sulit untuk melakukan administrasi, lalu juga birokrasi yang korupsi membuat ancaman yang besar untuk Indonesia karena membuat keterpurukan ekonomi nasional, persiapan SDM yang tidak menyeluruh menyulitkan Indonesia dalam bersaing di kancah ASEAN, lalu juga persaingan ekspor untuk produk Indonesia yang masih rendah masih harus ditingkatkan, dan persaingan mata uang dari Indonesia yang kecil.

Temuan penting dari penelitian ini adalah peluang Indonesia yang mau tidak mau akan berhadapan dengan pasar tunggal ASEAN yang harus dimanfaatkan. Dengan melihat posisi tawar Indonesia sebagai penduduk terbanyak di ASEAN, sudah seharusnya Indonesia mengambil pasar serta dapat berkompetisi dengan negara-negara lain di ASEAN. Lalu juga strategi seperti lebih menigkatkan pemeriksaan ekspor-impor secara bersih, perlunya stabilitas politik, lalu juga diharuskan adanya sikap untuk jauh dari korupsi, ketertiban sosial, inovasi, tenaga terampil, dan infrastruktur yang memadai. Dengan adanya temuan yang sudah dijabarkan diharapkan Indonesia tidak tertinggal jauh karena dilihat Indonesia mempunyai SDA dan SDM yang berlimpah. 


\section{DAFTAR PUSTAKA}

\section{BUKU:}

Balassa, Bela. The Theory of Economic Integration, London: Allen \& Unwin.1961

Burchill S , L Andrew. Teori-Teori Hubungan Internasional (Terjemahan). Jakarta: Nusa Media. 2009

Cipto, Bambang. ASEAN Economic Community, dalam Hubungan Internasional di Asia Tenggara, Tropong Terhadap Dinamika, Realitas, Dan Masa Depan. YogyakartaPustaka Pelajar. 2007

Cantori J, Louis \& Spiegel L, Steven (eds.). The International Politics of Regions: A comparative Approach. Englewood Cliffs, BJ: Prentice Hall. 1995

Direktorat Jenderal Kerjasama ASEAN.ASEAN Selayang Pandang Edisi ke- 19.Jakarta: Kementrian Luar Negeri Indonesia.2010

Direktorat Informasi dan Media.Mozaik Kiprah Keketuaan Indonesia pada ASEAN 2011. Jakarta: Direktorat Jenderal Informasi dan Diplomasi Publik Kemenlu RI. 2011

Damuri, Y.R. Trade Facilitation and Economic Development: Measuring the Impact. World Bank Policy Research 2988.Wilson, J.et al dalam.Fasilitasi Perdagangan dalam WTO dan Relevansinya bagi Indonesia, Analisis CSIS. 2006

Fawcett, Louis \& Hurrel, Andrew. Regionalism in World Politics: Regional organization and International Order. New York: Oxford University Press. 1995

Howard, M. War and Liberal Conscience. Oxford. 1978

Kurtz, D. L. Principle of Contemporary Marketing. Stamford: SouthWestern Educational Publishing. 2008

Marx, K. Grundisse. St. Albans.1970 
Morgenthau H, J. In Defense of the National Interest: A Critical Examination of American Foreign Policy. New York: University Press of America. 1951

Nazir, M. Metode Penelitian. Jakarta: Ghalia Indo.1998

Nugroho, Rian.Departemen Perdagangan RI: Menuju Asean

Economic Community, 2015. Jakarta:Gramedia 2012

Neuchterlein, Donald E. The Concept of National Interest: A Time New Approaches. ORBIS.Vol.23 No.1.1979

Papp D, S. Contemporary International Relation: A Framework for Understanding, Second Editions. New York: MacMillan Publishing Company. 1988

Porter E, Michael.Competitive Advantage: Creating and Sustaining Performance. NewYork: The Free Press. 1985

Rudy, T. Study Strategis dalam transformasi sistem Internasional Pasca Perang dingin. Bandung: Refika Aditama. 2002

Rangkuti, Freddy. Analisis SWOT Teknik Membedah Kasus Bisnis.Jakarta: PT. Gramedia Pustaka Utama. 2006

Suryabrata, Sumadi. Metode Penelitian. Jakarta: Cv Rajawali. 1989

Soehartono, Dr.Irawan. Metode Penelitian Sosial. Bandung: PT Remaja Rosdakarya. 2002

Smith, Michael. Regional and Regionalism: Issues in World Politics, Second Edition. New York: Palgrave. 2001

Smith H, Peter. Smith. Introduction: The Politics of Integration: Concepts and Themes, dalam Smith $\mathrm{H}$, Peter (ed.), The Challenge of Integration: Europe and the Americas. New Brunswick, NJ: Transactio. 1992

Sabir, M. ASEAN, Harapan, \& Kenyataan. Jakarta: Pustaka Sinar Harapan. 1992

Tsoukalis, Loukas. The New Europan Economy: The Politics and Economics of Integration. Oxford: OU. 1963 
Winantyo R, dkk. Masyarakat Ekonomi ASEAN 2015 Memperkuat Sinergi ASEAN di Tengah Kompetisi Global. Jakarta: Komputindo Kompas Gramedia. 2009

Winarno, Budi. Dinamika Isu-Isu Global Kontemporer. Yogyakarta: CAPS. 2014

\section{JURNAL:}

Jurnal Luar Negeri. Edisi Khusus II. Tahun 2011

KORAN/MAJALAH:

BEI News EdisiJanuari-Februari2004

Bisnis Indonesia. 7 Oktober 2003

Suara Karya, Selasa 5 April 2011

Media Indonesia, Jumat 29 April 2011

Kontan , Jumat 6 Mei 2011

Kompas, 6 Mei 2014

\section{SITUS INTERNET:}

http://www.jurnas.com/halaman/10/2011-11-19/189568

http://kominfo.jatimprov.go.id/watchp/1140

http://www.bbc.co.uk/indonesia/berita indonesia/2014/08/140826 pasar ten aga kerja aec

http://www.setneg.go.id/index.php?option=com content\&task=view\&id=7911 http://www.hukumonline.com/berita/baca/lt51d63934fofb0/strategi-

pemerintah-hadapi-aec-2015

http://disbun.jabarprov.go.id/index.php/artikel/detailartikel/46

www.weforum.org

http://berkas.dpr.go.id/pengkajian/files/info singkat/Info\%20Singkat-VI-10-IIP3DI-April-2014-4.pdf

http://www.tempo.co/read/news/2014/08/25/090602122/Menteri-EkonomiASEAN-Hanya-Teken-Dua-Kesepakatan 
http://www.kemenkeu.go.id/SP/pertemuan-ke-18-para-menteri-keuanganasean-18th-asean-finance-ministers-meeting-nay-pyi-taw http://pusatkln.setjen.pertanian.go.id/berita-198-pertemuan-tingkat-pejabatsenior-kementerian-pertanian-dan-kehutanan-asean-prepsomamaf-ke33.html http://www.esdm.go.id/siaran-pers/55-siaran-pers/6451-indonesia-tuanrumah-pertemuan-menteri-energi-se-asean-ke-31.html http://www.iesr.or.id/2011/12/eiti-diterima-dalam-kerjasama-mineral-asean/ www.antaranews.com/berita/450169/pertemuan-menteri-ristek-asean-bahas$\underline{\text { aec-2015 }}$ http://www.kemlu.go.id/penang/Lists/EmbassiesNews/DispForm.aspx?ID=68 http://dephub.go.id/welcome/readPost/sesjen-buka-pertemuan-aseantransport-facilitation-working-group-ke-27-61520 http://lpi.worldbank.org/ http://www.dbs.com/insights/conference/id/article-asia-penggerak-konsumsidunia.html www.asean.org 